JNUS:Journal of Nahdlatul Ulama Studies

Vol. 1, No. 1, Januari 2020: h. 17-33. DOI: 10.35672/jnus.v1i1.17-33

Website: http://jnus.lakpesdamsalatiga.or.id/index.php/jnus/index

\title{
The Role of Nahdlatul Ulama (NU) in Maintaining Religious Tolerance in Papua: Some Observations
}

\author{
Ridwan \\ Centre for Muslim States and Societies (CMSS) of University of Western Australia \\ ridwan117@gmail.com
}

\begin{abstract}
The presence of the Transnational Islamic Movement in Papua in the 1998 Reformation era has transformed the relationship between Muslims and Christians which had been harmoniously tense and could even lead to inter-religious conflict. One of the Islamic organizations in Papua working to maintain religious harmony is Nahdlatul Ulama (NU). Therefore, this paper aims to review how the NU responded to the Tolikara incident and the Koya Barat incident. Both cases related to the presence of the transnational Islamic actors in Papua, including Salafi-Wahhabi group, specifically Jafar Umar Thalib's faction in Papua, which has disturbed interreligious relations. This article argues that Nahdlatul Ulama (NU) plays a vital role in maintaining religious harmony that is in jeopardy with the presence of the transnational Islamic movement in Papua. This paper is based on data from fieldwork that the author has done from the end of 2015 to the early 2019 and is equipped with related library data.
\end{abstract}

Keywords: Tolikara incident, Koya Barat Incident, Nabdlatul Ulama, SalafiWabhabi, Christians

\begin{abstract}
Abstrak
Kehadiran Gerakan Islam transnasional di Papua di era Reformasi 1998 telah mengubah hubungan antar penganut agama Islam dan penganut Kristiani yang tadinya rukun menjadi tegang, bahkan bisa menjurus ke konflik antar agama. Salah satu ormas Islam di Papua yang bekerja untuk menjaga kerukunan beragama adalah Nahdlatul Ulama (NU). Karenanya, tulisan ini ingin mengulas bagaimana respon yang ditunjukkan oleh NU terhadap insiden Tolikara dan insiden Koya Barat. Kedua kasus tersebut terkait dengan kehadiran kelompok Salafi-Wahhabi, khususnya Faksi Jafar Umar Thalib di Papua, yang telah membuat hubungan antar agama terganggu. Tulisan ini beragumen bahwa Nahdlatul Ulama (NU) berperan cukup penting dalam menjaga hubungan beragama yang sedang dalam bahaya dengan kehadiran gerakan Islam transnasional di Papua. Tulisan ini bersumber dari data-data kerja lapangan yang penulis lakukan dari akhir
\end{abstract}


JNUS: Journal of Nahdlatul Ulama Studies, Vol. 1, No. 1, Januari 2020: 17-33

tahun 2015 hingga awal 2019 dan dilengkapi dengan data kepustakaan terkait.

Kata kunci: Insiden Tolikara, Insiden Koya Barat, Nabdlatul Ulama, SalafiWabhabi, Penganut Kristen

\section{INTRODUCTION}

This article endeavors to explain two leading case studies as an entry point to discuss the role of Nahdlatul Ulama (NU) Chapter Papua to maintain a religious tolerance in Papua region: Firstly, the Tolikara Incident. In the early morning of Friday, 17 July 2015, around 500 members of the Evangelical Church in Indonesia (Gereja Injili Di Indonesia, GIDI) attended the Ritual and Religious Revival Seminar (Seminar Kebaktian dan Kebangunan Rohani, KKR) in Karubaga, Tolikara. They attempted to stop Muslims from performing their Eid prayer in the yard of the 1702/JWY Sub-District Military Command (Koramil), which was followed by the burning of kiosks of transmigrants and a Mosque (Mushalla) Baitul Muttaqien. A 15-year-old school student died during the attacks. Eleven people were injured, and 70 kiosks were burnt including the Mosque as mentioned earlier. The event is popularly known as "The Tolikara Incident", which without doubt drew attention at both the local and national levels. Until now, several institutions have investigated 'the Tolikara Incident'. However, none have agreed upon the causes for the incident (al-Makassary 2017).

Secondly, "The Koya Barat Incident" that involved the Salafi group Jafar Umar Thalib (JUT). In December 2015, when Papuan Christians were celebrating the first week of Advent, public shook with news of conflict between a young Christian man and a young Muslim man who wanted to pray and felt disturbed by the noise of religious songs that were coming from the Christmas houses (Pondok Natal) that are a part of Christmas tradition in Jayapura, Papua. Local security officers resolved the conflict with no need to of judicial intervention or court proceedings. However, the young Muslim man was identified as a disciple of JUT, the former commander of Laskar Jihad in the Moluccas conflict between 
The Role of Nahdlatul Ulama (NU) in Maintaining Religious .... (Ridwan)

Muslims and Christians. Therefore, this raised concerns regarding escalating tensions between Christians and Muslims and future conflicts in the region.

To date, JUT and his disciples have created new problems regarding religious tolerance not only with Papuan Christians but also with Muslims. Since its arrival, there have been three incidents involving JUT's disciples against young Christian Papuans in Muaratami District, Jayapura. Recently, JUT and his disciples are building an Islamic boarding school (pesantren) in Keerom regency under firm resistance of some Muslims and Christians, as well as the local government in Papua. Here, I only limited the discussion of Nahdlatul Ulama (NU) responses of both cases because of the limited space.

Hence, to provide an in-depth and integrated picture about NU responses regarding the Tolikara Incident and Koya Barat Incident in Papua, this paper describes a general background of Papua briefly; describe the historical event of the Tolikara incident as a case study. Also, examine the presence and activities of JUT and demonstrates perceptions and responses of NU toward the Tolikara incident and the Koya Barat Incident (read: the JUT's jihad project). The author argues that NU played a significant role in promoting resolution of Tolikara through restorative justice. Meanwhile, in responding Salafi group of JUT, NU has resisted JUT's presence by collaborating with other stakeholders in preventing the establishment of pesantren of JUT in Arso 14, Keerom Regency. The data is based on the author fieldwork and observations from 2015 to 2018.

\section{DISCUSSION}

\section{Papua: a General Background}

Since the 1969 United Nations' Act of Free Choice (Penentuan Pendapat Rakyat, PePeRA), the mountainous half-island of Papua has had a troubled relationship with the Indonesian government. Local opposition to the widely criticised referendum led to the formation of the Free Papua Movement (Organisasi Papua Merdeka, OPM) that has led a low-level armed insurgency over several decades which the Indonesian government 
JNUS: Journal of Nahdlatul Ulama Studies, Vol. 1, No. 1, Januari 2020: 17-33

has suppressed with violence (Muridan 2010). Other causes for resentment on the part of the indigenous population include Papua's poverty relative to other parts of Indonesia and the large-scale influx of Muslim migrants that have tipped the demographic balance in some areas against the predominantly Christian Papuans. While the majority of Muslims in Papua live in peace with the indigenous population, the legalisation of Islamist political parties and organisations after the fall of Soeharto in May 1998 saw political and economic tensions in Papua increasingly framed along religious lines.

Indonesia has seen an Islamisation of the public sphere since 1998, with an increasing number of Shari'a banks, traditional Islamic schools, Islamic universities, and mosques. Radical transnational Islamic groups, including Hizbut Tahrir Indonesia (HTI), Jemaah Tabligh, and Salafi groups began to operate openly. The same process has occurred in Papua where it is more conspicuous because Papua has long been considered regarded as a predominantly Christian region.

The presence of transnational Islamic groups has sparked tensions not only with the indigenous Christian community but also within the Muslim community. Tensions are particularly apparent at the grassroots, where religious preachers contribute to the rise of prejudice, suspicion, mistrust, and misunderstanding between Muslims and Christians, often spilling over into violence.

With the resolution of the conflicts in the Moluccas, Central Sulawesi, and Aceh, Papua is the only region in Indonesia to be experiencing intermittent insurgency, although the Free Papua Movement has recently changed its approach from violence to diplomacy through internationalisation human rights abuses against Papuans. Grass root movements and civil society have given considerable attention, and to some extent, government, to conflict resolution and peacebuilding. When Joko Widodo (Jokowi) was elected as president in 2014 he vowed to give more attention to Papua and in the years since has visited regularly and carried out extensive development of infrastructure including roads, schools, ports, and hospitals in the province. 
Papua has begun to enjoy what Johan Galtung called "negative peace", but it still lacks "positive peace". Galtung defines "negative peace" as the absence of conflict or war and "positive peace" as the presence of cooperation, equality, a culture of peace and dialogue. In order to achieve positive peace, some civil society groups in Papua, such as Papuan Peace Network (Jaringan Damai Papua, JDP), have carried out peacebuilding. These organizations emphasize dialogue as a way to resolve Papuan conflict and try to get support from the Indonesian government and Papuan grass root movements and civil society.

\section{Two Cases of Radicalisation and Nahdlatul Ulama Responses}

To date, the advent of transnational Islam has resulted from suspicion among Christians, especially radicalisation that has been responded by Church Union to release Letter to ban building mosques as mentioned above, and fear of JUT's presence because of his track record in Moluccas conflict.

Historically, since the 1960s, the mainstream Islamic organizations in Indonesia have started their operations in Papua. The Nahdlatul Ulama (NU) has operated in Papua since 1967, while Muhammadiyah only came to the region with schools and clinics around the 1980s. Muhammadiyah had been present since 1942, but had not developed due to the Pacific war and protracted conflicts (Wanggai 2009). In 1971, these Islamic organizations united to found Yayasan Pendidikan Islam (YAPIS), which runs schools for Muslim children (Onim 2006).

Nahdlatul Ulama (NU), one of the most prominent Islamic mass organisations, in Indonesia, including Papua. In short, NU has developed in Papua with the arrival of transmigrants. Initially, NU was established in Fakfak with the first chairman was Abdullah Killian and Syarifuddin Rumoning as secretary. The advent of transmigrants, especially from South Sulawesi, established masjid Jami in Jayapura. The area of Masjid Jami is the Centre of Anshor youth movement, as well as the office of NU Chapter Papua (Wanggai 2009). 
JNUS: Journal of Nahdlatul Ulama Studies, Vol. 1, No. 1, Januari 2020: 17-33

Based on the writer observation, only Nahdlatul Ulama (NU) and its wing organisations such as Anshor and Banser have responded the threat of radicalisation brought by transnational Islam groups in Papua. Other Islamic mass organisations, including Muhammadiyah, have kept silent. Unfortunately, in some circumstances other organisations tended to support transnational Islamic actors that have operated in Papua. For example, some Muhammdiyah activists helped JUT in doing his activities in Keerom (Nursalim 2018). This is needed to be further studied.

This part will explore NU responses to Tolikara incident and JUT and its Islamic boarding school in Papua. However, before doing that, the author will discuss briefly a chronology of Tolikara incident and the dynamics of JUT and its pesantren that have got much resistance.

\section{First Case: The Tolikara Incident}

There are some versions of the Tolikara incident. Here is the writer version based on a fieldwork in Karubaga, Tolikara . Regional Working Committee Toli (Badan Pekerja wilayah Toli, BPWT) Evangelical Church in Indonesia (Gereja Injili Di Indonesia, GIDI) wrote a letter dated July 11, 2015, Letter No. 90 / SP / GIDI-WTT / VII / 2015. Subject: Notification to the Muslims in Tolikara. In essence, the letter indicates the BPWT GIDI announced that on 13-19 July 2015 there were seminars and KKR GIDI youth of international level.

In connection to these activities, the leadership of BPWT GIDI announced that: a) The event of Eid Fitry dated July 17, 2015, we are not allowed to do it in the area Tolikara and District Karubaga; b) It may conduct Eid Fitry outside Tolikara (Wamena) or Jayapura; c) NonMuslims (Muslimah) cannot use a headscarf; d) GIDI of Toli region prohibits other religions and other denominations to be created in Karubaga, Tolikara.

The letter was signed by Chairman BPWT GIDI Rev. Najus Wenda, S.Th, and Secretary Rev. Marthen Djingga, S.Th, MA. After that BPWT GIDI submitted to the Regent, Toli Regency House of Representatives and the police chief. The Circular Letter was received by 
Soeroso SH (served since September 2014) on Monday from members of the Intelligence Police Tolikara. Then, the Circular Letter dated 11 July, was reproduced and distributed to the Regent, the Chief of Parliament (Dewan Perwakilan Rakyat Daerah, DPRD) and the commander.

Meanwhile, Police have not received a request for permission and security assistance from the Executive Committee Seminar and Revival Service, 15-19 of July 2015. This is necessary as the basis for issuing a warrant of security assistance. In the morning the Deputy Police Chief visited and met KKR committee at the secretariat to ask about the letter. The Chief said, "If indeed there is the difficulty of making such a letter, it is necessary to help conceptualize after new conceptualized signed by the chairman and secretary." Because of the safety plan, permission from the Police Headquarters instead of the Police or local police has to be issued because the incident involves participants of foreign nationals, including Papua New Guinea (PNG) and Manus.

On the same day, the Regent and the Chairman of the Parliament were not in their offices. At 9:30 in the morning, the coordinator of the Police Chief in Karubaga made a conference call with the Regent, who was in Jakarta, and the following night he returned to Karubaga.

Regent tried to contact the head of BPWT, but he was not in Tolikara. The letter confirmed by the Chairman BPWT, it turned out and he indeed signed the letter, and then the Regent asked to revise the Circular Letter with the Eid prayers held in Musholla only. Because the preparation of a seminar on the KKR was not yet ready, the Regent asked the committee of the KKR to be postponed to October 2015. The committee denied any postponement because everything was scheduled in advance.

Early in the morning (15 July 2015), together with the Regent, the Police Chief and the Head of Parliament visited the District Panago and Giga, by Pilatus aircraft, where there was a tribal war. This conflict occurred from the date of July 9, 2015. In the afternoon, the Governor of Papua attended the Opening Seminar and KKR and not attended by the 
JNUS: Journal of Nahdlatul Ulama Studies, Vol. 1, No. 1, Januari 2020: 17-33

Regent. Afterward, at 19:00 p.m., there was the ribbon cutting of the GIDI Monument.

On the same day, the Revision Letter dated on 15 July 2015 was completed by the Organising Committee and signed by Mr. Djingga and Mr. Wenda. However, the letter just arrived on Saturday morning at the Police Office at Karubaga. Mr. Djingga confirmed this in front of the Police Chief at a meeting in Koramil on 22 July 2015.

Meanwhile, the Information Office of Ministry of Religious Affairs in Jayapura acknowledged that they had received the copy of permission requests to do KKR at 15:00 p.m., and employees have left work. On Thursday (16 July 2015), the Police Chief contacted the Regent by phone/SMS. Then, the Chief contacted President GIDI by phone reporting the planning of Eid in Tolikara. According to the Chief, plan to conduct Eid prayers at 06:30-7:30 a.m. because the Mushalla capacity is only 150 people, then disconnect the Eid prayers held on the Koramil front lawn.

Muslim certainly knew about the news of Eid at 18.00 p.m. from Jakarta. At night of takbiran only implemented in Mushalla by using the active speaker and without a parade. The Police Chief urged that people who were in the back heard Taraweeh, so there was no need to use loudspeakers outside. Usually, the speaker reasonably was placed in Mushalla, and active speakers were also put near the door, so the prayer would not be heard from outside. At that night, it was decided that Eid prayer would be held in the Koramil yard.

On Friday, 17 July 2015, people who wanted to pray Eid already started to gather at 06.00 a.m. Eid prayer was held at the Koramil within approximately 750 meters of the venue for the KKR using wireless devices, which have a range of about 200-300 meters. Meanwhile, KKR had not yet begun. Eid prayer was performed only until the 7 th Takbir because the masses of GIDI at the end of BPD office shouting: "Stop and Disband"! The first shooting by police was fired as a warning to the masses of KKR who seemed brutal and began to attack by throwing stones into Jemaah while they were conducting worship. 
The Police Chief said, "If there were no warning shots, the possibility of masses of KKR might not be controlled and there may have been more victims from the Jemaah, especially mothers and children. The masses went back". They gathered at the edge of the small airport near the Koramil field. But not long afterward another wave of mass came from the back of Mushalla. They were screaming to compel the congregation to stop their activities. Then after the first shooting, Eid prayer finally stopped.

Furthermore, at that time, the police chief who was using Muslim cloths (koko), and was requested to release his hat (songkok) and the chief did. Then, he and the Regent tried to stop and discuss with the leaders coming from the Street Irian. Therefore there was no further combustion. Then, he heard the sound of gunfire and then burning occured at the end of the pack kiosk of Mr. Sarno, near the Banyan tree.

At the end of the runway, shots were also heard. At the same time, smoke appeared behind the Banyan tree. The first kiosk burned was owned by Mr. Sarno, then the fire spread upwards and downwards. Then, the third stall, which sells gasoline and diesel, including cars, also caught fire. The Mushalla then started to burn. The fire was extinguished after 2 hours when 70 stalls were on fire and the Mushalla. One person died, and the 11 injured were evacuated to Wamena and Jayapura for treatment.

On Saturday, 18 July, 2015, the Revision letter dated 15 July, 2015, was brought into the police station, but it was unknown who brought the letter. On the same day, the Revision letter was received by Imam Ali Mukhtar. Meanwhile, at the meeting of the Chief of Police dated 22 July 2015, Mr. Djingga acknowledged that he signed the letter with Mr. Wenda confirming that he wrote it on 15 July.

\section{Responses of Nahdlatul Ulama Chapter Papua on Tolikara Incident}

To date, NU is very active in promoting religious tolerance, including searching for ways to handle the Tolikara incident and its broader implications to religious tolerance in Papua. The chairman of NU Papua region, Dr. Toni Wanggai, MA, was very keen in solving Tolikara incident. 
JNUS: Journal of Nahdlatul Ulama Studies, Vol. 1, No. 1, Januari 2020: 17-33

In short, positive responses of NU regarding the Tolikara incident, including attending a meeting to discuss future Tolikara research and mediate a peaceful solution to the conflict.

A day after the event, Mr. Wanggai, including the author, were active in attending meetings with stakeholders that have been initiated by the chairman of the Ministry of Religious Affairs (Kemenag) of Papua. In that meeting, stakeholders released a letter to calm down the ummah and give time to police institution to instigate the case comprehensively.

Furthermore, NU invited Imam of Tolikara, Ali Mukhtar, to come to Jayapura and met stakeholder to discuss the event and find a peaceful solution. Mr. Mukhtar was invited to join Muktamar in Jombang as well. Before moving to Jombang, the author interviewed Mr. Mukhtar to get a holistic picture of the role played by Islam in this incident. Besides, the three of us (Mr. Wanggai, Mr. Mukhtar, and the author) had conducted regular meetings with GIDI representative in Jayapura to find a solution through the means of restorative justice.

A few days after the event, the author as a member of NU and a special staff at Religious Leader Forum for Tolerance (Forum Kerukunan Umat Beragama, FKUB) Papua representing NU and joined a fact-finding team that was created by FKUB Papua to visit Karubaga to collect data and for doing participant observation. After collecting data, the team argued that "Tolikara incident" as not a religious conflict, because there was no physical confrontation between Muslims and GIDI's members, and relations between both communities are good. The cause of the incident was miscommunication between the stakeholders. For example, there is no good (missing) communication about the notification for revision by letter on 15 July 2015 over the Letter on 11 July 2015 that prohibits Muslims to conduct Eid prayer in Karubaga as well as prohibit women (Muslimah) to wear a veil. The first letter was assumed as a source of the incident. Unfortunately, the second letter revising the first letter was not given to the local police head and Imam (Muslims leader) because of bad communication. 
Finally, 29 July 2015 was a historical date since both parties agreed to sign a peace and tolerance agreement. Seven points were agreed, for example both parties recognised the need to forgive each other sincerely; agreed to build a new Mosque; agreed on problem-solving by using cultural or customary laws; agreed to conduct regular monitoring for future tolerance and peacebuilding in the region. In short, these points were rooted in peaceful relations for years between both communities. To conclude, Nahdlatul Ulama (NU) has played a significant role by bringing leaders from both communities together in FKUB office to negotiate a lasting solution.

\section{Second Case: Jihad Project of JUT in Jayapura and Keerom}

The presence of JUT in Papua, no doubt, is related to the Tolikara incident. On 15 July 2015, the Tolikara incident occurred and drew attention globally and nationally. Indonesian Muslims without knowing the case comprehensively have condemned the event. On 20 July 2015, JUT issued the declaration of Jihad Fisabilillah to Papua. The declaration proclaimed war in retaliation for attacks against the GIDI group that attacked the Tolikara Muslims. Also, JUT stated that the Government of Indonesia as a kafir (infidel) (Al-Makassary, 2017).

Two months after the Incident, JUT ordered two of his followers going to Papua to look for land to set up pesantren. In October 2015, both arrived and found a rented house in Koya Barat, Muaratami District, Jayapura. The district is located near the border of Papua New Guinea. Koya Barat can be reached by bus or car for about an hour from Jayapura. For years, Muslims transmigrants from Jawa have lived with indigenous Papuan Christians in communal harmony.

The Muslim community accepted JUT's members after staying two months in Koya Barat. Fauzi, one of the members, had given sermons frequently in mosque Al Muhajirin including eight mushallas. As a result, many Muslims were attracted with Fauzi's Islamic teaching. After settling in Koya, Fauzi contacted JUT, and in November 2015, JUT and his 40 disciples came secretly. 
JNUS: Journal of Nahdlatul Ulama Studies, Vol. 1, No. 1, Januari 2020: 17-33

What were the motives of JUT and his disciples to come to Papua? In the meeting with a team created by the Mayor of Jayapura, JUT said his presence was to establish a pesantren because morals of the Indonesian nation were broken and it would be healed from Papua. JUT did not mention the Tolikara incident as the main reason that brought him to come to Papua. Also, JUT stated, "The Mollucas conflict was his past and now he wanted to preach to Indonesian people through education from Papua”.

However, the Tolikara Incident was an apparent reason for JUT to come to Papua. We noted, in responding to the incident, JUT echoed the declaration of Jihad Fisabillillah to Papua, as mentioned above. In this sense, Abu Yahya, a member of JUT, justified this reason by saying that JUT was "seeing" Papua as a place for jihad because of the Tolikara incident. Fortunately, the Indonesian Government handled the incident quickly. In this regard, Abu Yahya said, "If the Tolikara incident was not resolved, JUT had given a command to 50 members for doing Jihad to burn entire churches in Papua".

Meanwhile, some leaders in Papua assumed there were indications of involvement of Indonesian police to facilitate JUT's presence in Papua. According to local sources, "From the beginning, we suspected JUT"s presence was related to the police elite in Jakarta. JUT mentioned that he was backed up by a former police chief. We need to find out on this". Besides, according to another local source, "The failure of his jihad project in Indonesia and the bankruptcy of his pesantren in Yogyakarta inspired JUT to perform his Jihad project in Papua."

Thus, JUT started preaching Islamic teaching based on Wahhabi in Keerom and its surrounding vicinity. Usually, he gives sermons after Subuh prayers in some mosques. In the same vein, Hasan (2009) stated that the education system in JUT's pesantren in Yogyakarta and some pesantren affiliated with JUT is conservative, thereby the educators deny teachings and activities that have been contaminated by Western culture and challenged traditional religious corpus. Hence, Wahhabism became the teaching foundation and leading Islamic doctrine in this region. 
The Role of Nahdlatul Ulama (NU) in Maintaining Religious .... (Ridwan)

JUT and his disciples not only teach Islamic ideas based on Wahhabism understanding but also distribute books entitled Jihad Fisabilillah and The Black Notes of Shia Religion and videos which were related to the are based on Wahhabi teaching to Muslims living in areas such as Koya Barat areas around it. According to a local report, JUT had built up his prestige through teaching and distributing his books. Hence, some Muslims in Koya perceived him as a hero for Muslims in Papua.

Most importantly, the main idea of JUT's arrival is to set up a pesantren. In doing so, since staying in Koya Barat, JUT and his disciples were busy looking for a suitable place to disseminate Wahhabism across Keerom and the region. Keerom shares a border with Papua New Guinea. This region has many Muslim transmigrants, especially from Java that work for trading, farming, and fishing. Now, the percentage between Muslims and Papuan Christians is 40:60. However, one local source stated that "In reality, Muslims are more in number than Christians".

In the beginning, JUT planned to buy land in Arso 1, but he faced obstacles from the landowner and the leader of the ethnic tribe (ondoafi). Finally, JUT bought 26.5 hectares in Arso 14. He will be dividing the land for the building of the Pesantren on five hectares; for agriculture, four hectares; for plantations, ten hectares; and for farms, seven and a half hectares. Besides, JUT bought 200 hectares that will be used for sugar cane farming. In this regard, my informant said JUT bought costly land. He added, "We do not know about the sources of the funds. We heard JUT got it from the political elite in Jakarta. However, this needs more clarification". Also, the purpose of buying the land also was misused by JUT. Senior staff at the local government in Jayapura, Evert Meraudje, said, "JUT bought land for farming and he changed it for building the pesantren."

JUT planned, after establishing pesantren in Arso 14, to establish 20 pesantrens in Papua. According to a local statement, "This is based on JUT's experience in the war in Afghanistan against the Soviet Union. Starving for logistical support was the cause of the defeat of the Soviet army. Consequently, JUT will establish pesantren with the concept of 
JNUS: Journal of Nahdlatul Ulama Studies, Vol. 1, No. 1, Januari 2020: 17-33

agriculture, plantation, and animal husbandry to meet their own logistical needs. So, the incident that afflicted the Soviet troops in Afghanistan will not happen". In this regard, it seems that JUT is preparing for a conflict between Muslims and Christians in the future.

To manage the building of the pesantren, JUT chose his son, Amir Thalib. Four santris and two craftsmen have assisted Amir. The name of the pesantren is Ihya Us Sunnah, the same name of JUT's pesantren in Yogyakarta. In establishing his first pesantren in Keerom, nevertheless, JUT received resistance from Islamic organisation, peacebuilding and the Papuan government.

\section{Responses of Nahdlatul Ulama Chapter Papua on Jihad Project of JUT}

The local population is deeply concerned that JUT's presence in the region will spark a new conflict between Muslims and Christians because JUT had led the Laskar Jihad fighting Christians in the Moluccas conflict. Hence, JUT has gotten much resistance, and this part will describe the key actors' perceptions and responses of him.

Nahdlatul Ulama's rejection of JUT's presence in the region was based on the following reasons: Firstly, JUT's track record was filled with violence and intolerant acts in Ambon and Yogyakarta. Muslims in Papua do not want a religious conflict to happen in Papua such as Moluccas conflict that involved JUT and his Laskar Jihad. Secondly, communal harmony amongst Muslim groups in Papua is good without an attempt to call them infidels or blame other groups. Thirdly, JUT's attitude in his declaration "War against pluralism" is denying of Sunatullah (Allah's will) and it will create tension with non-Muslims in Papua.

According to NU statement, "For Muslims in Papua, pluralism is necessary and God's will. We found many religions in one extended family. JUT's track record did not represent a peaceful Islam. Muslim leaders in Papua have been struggling to show a peaceful Islam. We are worried JUT's arrival will diminish our project to build up Papua Land of 
Peace. This collective vision cannot be stopped by anyone, including JUT and his disciples".

Overall, considering all suggestions from participants in the meeting, MUI Papua, including NU, released the recommendation that JUT needs to leave Papua. Muslim groups in Papua can maintain their religion without the intervention of groups that tended to claim they were more innocent and more truthful than others like JUT's teachings.

\section{Responses of Stakeholders in Keerom Regency}

Stakeholders (the local government, MUI, NU, Papuan Christians, and interfaith groups) in Keerom felt disturbed when JUT was looking for land to build his pesantren in Keerom. The stakeholders are concerned that JUT's arrival will destroy communal harmony in the region of Keerom.

The stakeholders held some meetings to respond to JUT's arrival in Keerom. The chairman of NU in Keerom, Nursalim, said that the group has invited JUT for tabayyun (discussion), but he never came. He added, "JUT as a guest never met us to discuss his plans. Instead, he was building his pesantren without asking for permits from the local government. However, in the mass media JUT told differently that things were being complicated for him to be able to get the permits. This is not true!"

The stakeholders agreed to stop constructing JUT's pesantren after a meeting with the representative of National Commission of Human Rights of Indonesia (Hak Asasi Manusia, HAM), the Chief of Papuan police, MUI, Islamic mass organisations, etc. The local government in Keerom has issued the three warning letters related to the building permits of pesantren, but JUT did not respond to it. Nursalim said "The third letter was given as an ultimatum to him to immediately vacate the land and stop the building of the pesantren".

The building of JUT's pesantren stopped because there is too much resistance. A semi-permanent pesantren has been built, including a mosque that is used for activities of JUT, such as for prayers and religious 
JNUS: Journal of Nahdlatul Ulama Studies, Vol. 1, No. 1, Januari 2020: 17-33

gatherings. JUT and his disciples are still preaching in some places in Keerom, including in Arso 10, a place of Muhammdiyah in Keerom. Even the local government elite that supported JUT's pesantren give him space for preaching.

\section{CONCLUSION}

The Tolikara incident and presence of JUT and his disciples in Papua (Jayapura, Sentani and Keerom), had sparked tension within Muslims and non-Muslims. In short, stakeholders resolved the Tolikara incident, including the important role, had been played by NU, as mentioned above. However, JUT case is still unresolved. In particular, a plan to establish pesantren as a site of preaching Wahhabi Salafism triggered strong protest from NU, Papuan Christians and Islamic mass organisations in MUI. In reality, JUT and his disciples are enduring in Keerom and teaching their Islamic ideas.

\section{BIBLIOGRAPHY}

Al-Makassary, Ridwan dkk, Masjid dan Pembangunan Perdamaian, Jakarta: CSRC, 2011

Al-Makassary, Ridwan, Damai Papua Damai Indonesia, Yogyakarta: Kementrian `Agama Papua, 2015

Al-Makassary, Ridwan, Dialog dan Radikalisme Agama di Tanah Papua, Yogyakarta: FKUB Papua, 2016

Al-Makassary, Insiden Tolikara dan Jafar Umar Thalib: Kontroversi Mushalla yang dibakar dan Drama Jihad di Tanah Papua, Yogyakarta: Kementrian Agama Papua, 2017

Hasan Noorhaidi, Laskar Jihad: Islam, Militansi, Dan Pencarian Identitas Di Indonesia Pasca Orde Baru, Jakarta: LP3ES, 2006 Jones, Sydney, INDONESIA: COMMUNAL TENSIONS IN PAPUA Asia Report N¹54 - 16 June 2008. Diakses pada 5 November 2017 dalam 
The Role of Nahdlatul Ulama (NU) in Maintaining Religious .... (Ridwan)

http://www.genocidewatch.org/images/Indonesia_08_06_16_Communa 1_Tensions_in_Papua.pdf

Wanggai, Toni Victor M, Rekonstruksi Sejarah Umat Islam di Tanah Papua, Jakarta: Badan Litbang dan Diklat Departemen Agama, 2009

Widjojo, Muridan. S, dkk, Papua Road Map: Negotiating the Past, Improving the Present and Securing the Future, Jakarta: Yayasan Obor, 2010

Various interviews with informants during my fieldwork research in Papua 